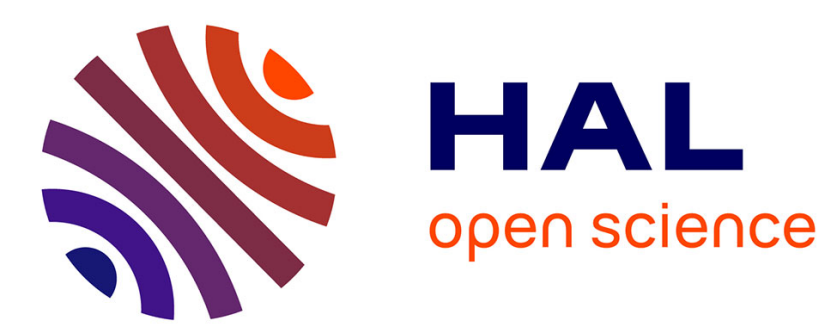

\title{
Equation of state of Al-bearing perovskite to lower mantle pressure conditions
}

Isabelle Daniel, Hervé Cardon, Guillaume Fiquet, François Guyot, Mohamed

Mezouard

\section{- To cite this version:}

Isabelle Daniel, Hervé Cardon, Guillaume Fiquet, François Guyot, Mohamed Mezouard. Equation of state of Al-bearing perovskite to lower mantle pressure conditions. Geophysical Research Letters, 2001, 28 (19), pp.3789-3792. 10.1029/2001GL013011 . hal-00232775

\section{HAL Id: hal-00232775 \\ https://hal.science/hal-00232775}

Submitted on 8 Feb 2021

HAL is a multi-disciplinary open access archive for the deposit and dissemination of scientific research documents, whether they are published or not. The documents may come from teaching and research institutions in France or abroad, or from public or private research centers.
L'archive ouverte pluridisciplinaire HAL, est destinée au dépôt et à la diffusion de documents scientifiques de niveau recherche, publiés ou non, émanant des établissements d'enseignement et de recherche français ou étrangers, des laboratoires publics ou privés. 


\title{
Equation of State of Al-bearing Perovskite to Lower Mantle Pressure Conditions
}

\author{
Isabelle Daniel and Hervé Cardon \\ Laboratoire de Sciences de la Terre UMR 5570 CNRS-ENS Lyon-UCB Lyon 1, France \\ Guillaume Fiquet and François Guyot \\ Laboratoire de Minéralogie-Cristallographie UMR 7590 CNRS-Université Paris VI, France
}

\section{Mohamed Mezouar}

European Synchrotron Radiation Facility, Grenoble, France

\begin{abstract}
Al}_{2} \mathrm{O}_{3}$ is estimated to total 4 to $5 \mathrm{~mol} \%$ in all mantle compositional models, and is believed to be incorporated into $(\mathrm{Mg}, \mathrm{Fe}) \mathrm{SiO}_{3}$-perovskite at lower mantle conditions. Using synchrotron $\mathrm{X}$-ray diffraction, we have measured the $300 \mathrm{~K}$ equation of state of a perovskite with $\mathrm{X}_{\mathrm{Al}}=$ $\mathrm{Al} /(\mathrm{Al}+\mathrm{Mg}+\mathrm{Si})=.077$, up to $32 \mathrm{GPa}$. A least squares refinement of two independent data sets yields the following equation of state parameters $V_{0}=163.52(3) \AA^{3}, K_{0}=229(4)$ $\mathrm{GPa}$, and $K_{0}=2.5(4)$. These values allow us to assess the most probable substitution mechanism for aluminium into perovskite at pressure conditions of the shallow lower mantle. $\mathrm{Al}^{3+}$ is likely to be incorporated in place of $\mathrm{Si}^{4+}$ in the octahedral site of perovskite, hence requiring the creation of oxygen vacancies for charge balance. As a consequence, aluminous perovskites may have a high affinity for water. The enhanced compressibility of aluminous perovskite certainly has also strong geophysical and geochemical implications, as it may revive perovskite-rich lower mantle models.
\end{abstract}

\section{Introduction}

Much effort has been devoted in the last five years to characterize the thermal equation of state of the main phases constitutive of the lower mantle up at pressures and temperatures prevailing at these depths. Within the frame of a three components system $\left(\mathrm{MgO}-\mathrm{FeO}-\mathrm{SiO}_{2}\right)$, all recent experimental work or calculations on $(\mathrm{Mg}, \mathrm{Fe}) \mathrm{SiO}_{3}$-perovskite and $(\mathrm{Mg}, \mathrm{Fe}) \mathrm{O}$ magnesiowustite yield convergent results that a pure perovskite lower mantle is either very unlikely or very hot [Gillet et al., 2000]. At temperatures most commonly accepted for the lower mantle, silicate perovskite would have bulk modulus values significantly higher than those predicted from the bulk modulus $K_{T}$ profile of PREM [Dziewonsky and Anderson, 1981]. When minor components are further taken into account in calculating the thermoelastic profile of a lower mantle mineralogical model, $\mathrm{Ca}$ is often the next one considered [Wang et al., 1996; Shim et al., 2000]. Since $\mathrm{Al}$ does not enter a separate aluminous phase in the lower mantle, but is rather dissolved into $(\mathrm{Mg}, \mathrm{Fe}) \mathrm{SiO}_{3}$-perovskite, with lesser amounts accepted into $\mathrm{CaSiO}_{3}$-perovskite [Irifune, 1994], Al has always been ignored in such models.

Copyright 2001 by the American Geophysical Union.

Paper number 2001 GL013011.

0094-8276/01/2001GL013011\$05.00
However, various experimental data have indicated that the presence of $\mathrm{Al}$ in perovskite causes significant changes in the chemical and physical properties of silicate perovskite. Due to $\mathrm{Al}$, the stability field of perovskite is extended toward iron-rich compositions [Kesson et al., 1995]. Al-bearing perovskite has essentially the same $\mathrm{Fe} /(\mathrm{Fe}+\mathrm{Mg})$ ratio as coexisting magnesiowustite, whereas $\mathrm{Fe}$ has a stronger affinity for magnesiowustite in the Al-free system [Wood and Rubie, 1996]. Al has also been shown to enhance the proportion of ferric iron in perovskite [McCammon, 1997], yielding an electrical conductivity about 3.5 times greater than that of an $\mathrm{Al}$-free perovskite [ $\mathrm{Xu}$ et al., 1998].

Finally, Zhang and Weidner [1999] recently measured the effect of $\mathrm{Al}$ on the equation of state of perovskite. For an Al-content typical of the pyrolite composition, $\mathrm{X}_{\mathrm{Al}}=$ $\mathrm{Al} /(\mathrm{Mg}+\mathrm{Si}+\mathrm{Al})=.05$, they showed that the bulk modulus $\mathrm{K}_{0, T}$ of $\mathrm{Al}$-perovskite is about $10 \%$ smaller than that of the end-member $\mathrm{MgSiO}_{3}$-perovskite, whereas its temperature derivative is much larger. Since such results change dramatically the constraints on the mineralogical composition of the lower mantle, we present here the equation of state to lower mantle pressure conditions, for a slightly more aluminous magnesium silicate perovskite characterised by $\mathrm{X}_{\mathrm{Al}}=.077$, which will be designated as $\mathrm{Al}_{.077}-\mathrm{pv}$.

\section{Experimental Procedure}

Angle dispersive $\mathrm{X}$-ray diffraction experiments were carried out in a membrane-type diamond-anvil cell at the ID30 high-pressure beamline of the ESRF (Grenoble, France). The incident monochromatic X-ray beam $(\lambda=0.3738 \AA)$ was doubly focused and filtered to achieve a $10 \times 15 \mu \mathrm{m}^{2}$ spot on the sample. The diffracted signal was collected for 20 to 120 s, over a $2 \theta$ interval from 4 to $25^{\circ}$ either on a MAR345 or on the FastScan detector.

Two P-V data sets were acquired for $\mathrm{Al}_{.077}-\mathrm{pv}$ samples synthesized from a $\mathrm{Py}_{31} \mathrm{Mj}_{69}$ synthetic glass containing 7.7 mol\% $\mathrm{Al}_{2} \mathrm{O}_{3}$. The starting glass was transformed into perovskite at $35 \mathrm{GPa}$ and $1800 \pm 200{ }^{\circ} \mathrm{C}$ by laser heating with a $\mathrm{CO}_{2}$ laser. The first sample was synthesized using potassium bromide as a pressure transmitting medium; it was afterward unloaded and triply washed in distilled water. The recovered $15 \mu \mathrm{m}$ thick perovskite platelet was subsequently reloaded with ruby chips and $\mathrm{He}$ as a pressure transmitting medium. Diffraction patterns were then collected upon raising pressure to $24 \mathrm{GPa}$. The second sample was loaded 


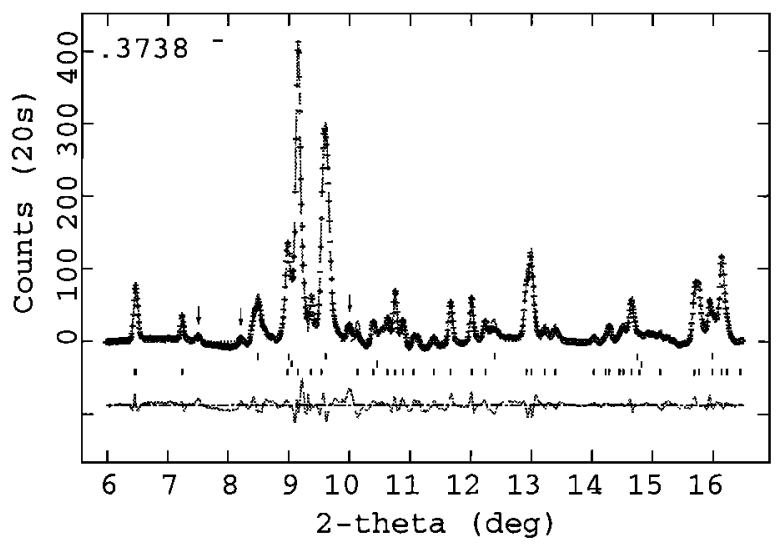

Figure 1. Integrated angle dispersive diffraction pattern of $\mathrm{Al}_{.077}$-pv collected at $32 \mathrm{GPa}$. The difference between experimental intensities and the best LeBail refinement profile is shown at the bottom. Three series of ticks corresponding to the reflection lines of perovskite (bottom), fcc-argon (middle) and hcp-argon (top) are represented. Arrows point to weak unrefined reflections which could correspond to small amounts of stishovite and ilmenite (less than $1 \%$ ).

cryogenically in Ar, with ruby chips. The glass was transformed into perovskite at $35 \mathrm{GPa}$; diffraction patterns were then recorded along the decompression path.

Two-dimensional images were integrated after spatial distorsion and background corrections using the program Fit2D [Hammersley, 1997], and processed using the GSAS package [Larson and Von Dreele, 1988]. Le Bail full-profile refinements were applied to the diffraction patterns, in order to obtain reliable high-pressure cell parameters for Al-bearing perovskite (Fig. 1).

\section{Results and Discussion}

\section{Axial Compressibilities and Distorsion}

The variation of unit cell parameters as a function of pressure ${ }^{1}$ is plotted in Fig. 2. At ambient pressure, $\mathrm{Al}_{077}$ pv lattice parameters are consistent with the dependence on $\mathrm{Al}$ content previously reported for perovskite [O'Neill and Jeanloz, 1994; Irifune et al., 1996; Kubo and Akaogi, 2000]. Subsitution of $7.7 \% \mathrm{Al}$ expands the structure by $\sim 0.7 \%$, and causes an increased distorsion in both $a / b$ and $a / c$ ratios relative to $\mathrm{MgSiO}_{3}$. As pressure is raised, the present data show that $\mathrm{Al}_{077}-\mathrm{pv}$ is elastically strongly anisotropic, with the $b$ axis being approximately $30 \%$ less compressible than $a$ and $c$ (Fig. 2). Since all unit-cell parameters do not decrease linearly between 0 and $32 \mathrm{GPa}$, we calculate the axial compressibilities between 0 and $10 \mathrm{GPa}$, which allows comparison with the available data (Table 1 ). Whereas the $b$ axis compressibility seems almost insensitive to $\mathrm{Al}$ substitution, we do observe a strong linear increase of both $a$ and $c$ compressibilities with $\mathrm{Al}$ content.

Reported in Fig. 3 are the variations of cell edge ratios $a / b$ and $\sqrt{2} a / c$ as functions of pressure. These ratios may be related to the commonly used $\theta$ and $\Phi$ angles, needed

\footnotetext{
${ }^{1}$ Supporting material is avalable-via Web- browser- or-via Anonymous FTP from ftp://kosmos.agu.org, directory "apend" (Username = "anonymous", Password = "guest"); subdirectories in the ftp site are arranged by paper number. Information on searching and submitting electronic supplements is found at http://www agu.org/pubs/esupp_about html.
}

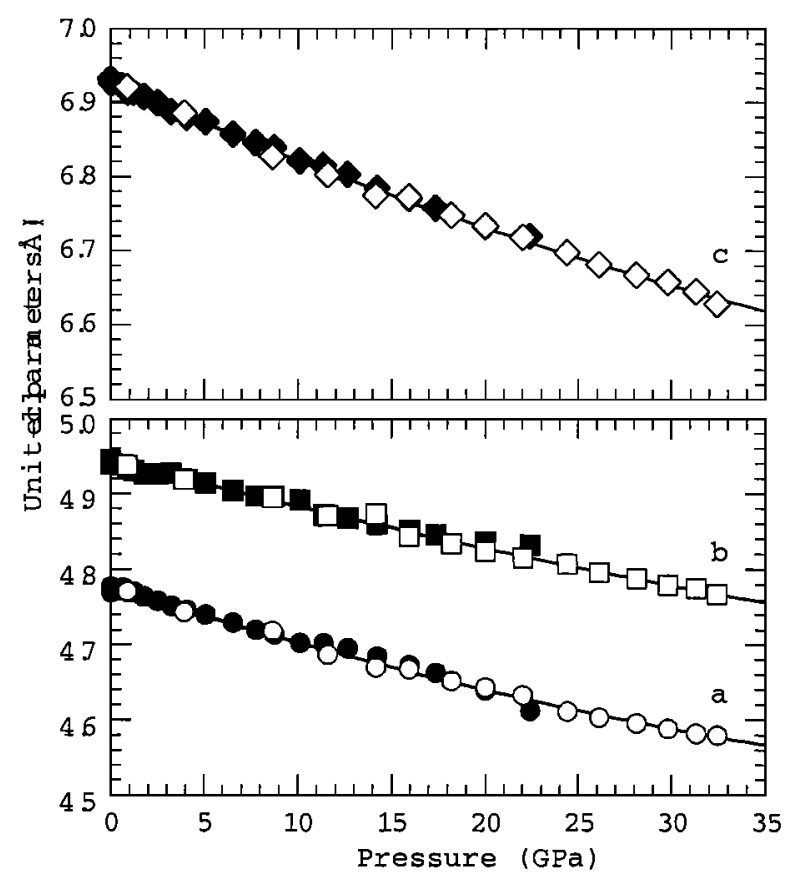

Figure 2. Pressure dependence of the unit-cell parameters of Al.o77-pv. Circles, squares and diamonds represent respectively the $a, b$ and $c$ cell-edges. Filled and empty symbols designate data acquired respectively in $\mathrm{He}$ and $\mathrm{Ar}$. The solid lines are guidesfor-the-eye.

to describe the coupled octahedral rotations about the respective [110] and [001] pseudocubic axes. Assuming a rigid behaviour for the octahedra, departure of these rotational angles from 0 provides an approximate representation of the orthorhombic distortion in perovskite. At ambient condition, $\mathrm{Al}_{\text {. }}$.77 -pv structure is characterised by $\theta=14.9^{\circ}$ and $\Phi=$ $12.7^{\circ}$, and is thus slightly more distorted than $\mathrm{MgSiO}_{3}$ perovskite. With increasing pressure, $\theta$ first increases rapidly up to $\sim 10 \mathrm{GPa}$, and then rises slower than in $\mathrm{MgSiO}_{3}$ perovskite, leading to an overall linear behaviour of $\cos \theta \operatorname{simi-}$ lar to that of $\mathrm{MgSiO}_{3}$ perovskite over the entire investigated pressure range. At difference, $\Phi$ remains almost constant in $\mathrm{Al}_{077}$-pv between 0 and $32 \mathrm{GPa}$, while it slightly increases in $\mathrm{Al}$-free perovskite. This indicates a common compression behaviour in the basal plane for Al-free and Al-bearing perovskites, but a distinct compression mechanism along the $c$ axis.

Table 1. Linear compressibilities, bulk modulus, and their dependence on the Al content of perovskite in the 0-10 GPa range.

\begin{tabular}{ccccc}
\hline $\mathrm{X}_{\mathrm{Al}}$ & $\begin{array}{c}\beta_{a} \\
10^{-3} \mathrm{GPa}^{-1}\end{array}$ & $\begin{array}{c}\beta_{b} \\
10^{-3} \mathrm{GPa}^{-1}\end{array}$ & $\begin{array}{c}\beta_{c} \\
10^{-3} \mathrm{GPa}^{-1}\end{array}$ & $\begin{array}{c}K_{0} \\
\mathrm{GPa}\end{array}$ \\
\hline $0^{\dagger}$ & $1.30(5)$ & $1.04(4)$ & $1.24(4)$ & $254(13)$ \\
$.05^{\ddagger}$ & $1.39(4)$ & $1.20(4)$ & $1.42(5)$ & $234(3)$ \\
.077 & $1.49(3)$ & $1.02(4)$ & $1.54(3)$ & $224(3)$ \\
\hline $\mathrm{d} / \mathrm{dX}_{\mathrm{Al}}$ & $2.4(5)$ & $.0 .0(3)$ & $3.9(2) \ldots$ & $-3.9(1) 10^{2}$ \\
\hline
\end{tabular}

${ }^{\dagger}$ from Ross and Hazen [1990]

${ }^{\ddagger}$ from Zhang and Weidner [1999] 


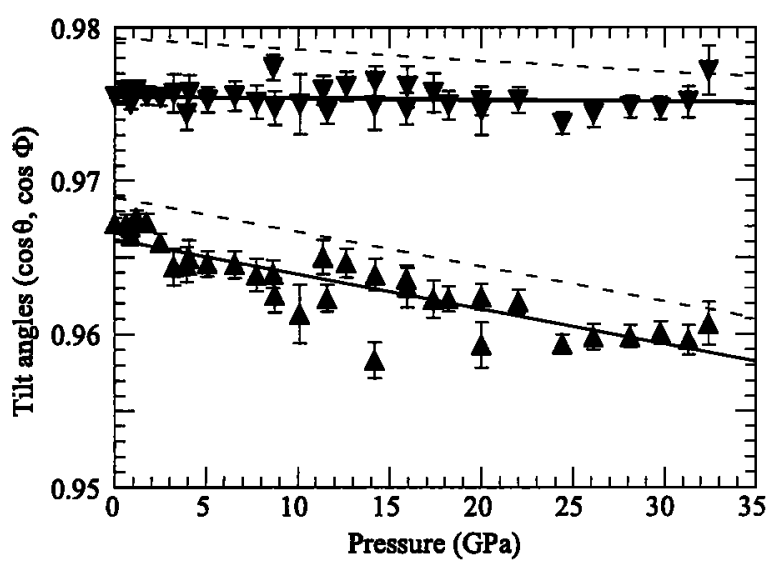

Figure 3. Variation of $\cos \theta=a / b$ (up triangles) and $\cos \Phi=$ $\sqrt{2} a / c$ (down triangles) for $\mathrm{Al} .077$-pv as a function of pressure. A linear fit to the data (solid line) indicates that $\Phi$ remains almost constant up to $32 \mathrm{GPa}$. The evolution of the tilt angles for $\mathrm{MgSiO}_{3}$-perovskite (dashed line) is reported for comparison.

\section{Equation of State}

The variation of the unit-cell volume of $\mathrm{Al}_{.077}$-pv with pressure is shown in Fig. 4. The pressure-volume data from the two runs were combined for a least square fit to a BirchMurnaghan equation of state truncated to the $3^{\text {rd }}$ order. Using all of the data, a bulk modulus $K_{0}=229(4) \mathrm{GPa}$, a pressure derivative $K_{0}^{\prime}=2.5(4) \mathrm{GPa}$ and a room pressure unit-cell volume $V_{0}=163.52(3) \AA^{3}$ are obtained. Both values of $K_{0}$ and $K_{0}^{\prime}$ for $\mathrm{Al}_{\text {.077 }} \mathrm{pv}$ are much lower than those characteristics of $\mathrm{MgSiO}_{3}$ perovskite [Fiquet et al., 2000]. This demonstrates that Al-bearing perovskite is much more compressible than Al-free perovskite, at least up to pressures characteristic of the shallow lower mantle (Fig. 4).

Since all bulk moduli available for Al-bearing perovskites have been determined assuming $K_{0}^{\prime}$ equal to 4 [Zhang and Weidner, 1999; Brodholt, 2000], we also adjusted our data to a $2^{\text {nd }}$ order Birch-Murnaghan equation between 0 and $10 \mathrm{GPa}$. We calculate $K_{0}=224(3) \mathrm{GPa}$ and $V_{0}=163.52(3)$ $\AA^{3}$, when $K_{0}^{\prime}$ is set to 4 . This value of the bulk modulus is in excellent agreement with that obtained by Zhang and Weidner [1999], and therefore indicates a steep decrease of the bulk modulus as the aluminium content in perovskite

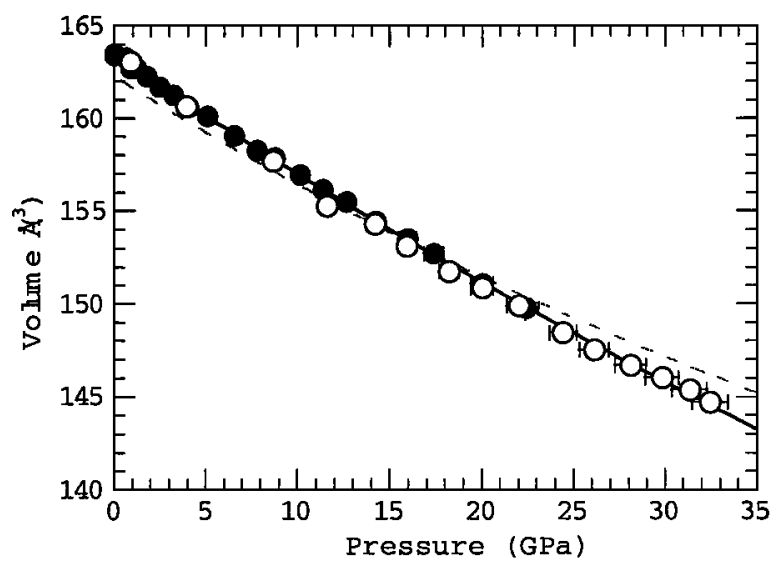

Figure 4. Birch-Murnaghan equation of state of $\mathrm{Al} .077-\mathrm{pv}$ (solid line). Filled circles: experiment in He; empty circles: experiment in Ar. Al.o77- pv becomes denser than pure $\mathrm{MgSiO}_{3}$-perovskite (dashed line) above approximately $17 \mathrm{GPa}$. increases (Fig. 5). We derive a slope of $-3.9(1) 10^{2} \mathrm{GPa}$ for the dependence of the bulk modulus of perovskite on the aluminium fraction $\mathrm{X}_{\mathrm{Al}}$ (Table 2).

The large difference between both elastic parameters $K_{0}$ and $K_{0}^{\prime}$ for pure $\mathrm{MgSiO}_{3}$-perovskite and $\mathrm{Al}_{.077}$-pv, together with their distinct anisotropy and pressure-induced crystallographic distortion tend to indicate that the compression mechanism of the perovskite structure evolves significantly even when a small amount of $\mathrm{Al}$ is dissolved. This suggests that the crystal chemistry of aluminous perovskites might be rather different from $\mathrm{MgSiO}_{3}$-perovskite.

\section{Implications for the Substitution Mechanism of Al into Perovskite}

Two substitution mechanisms have been proposed for the incorporation of $\mathrm{Al}^{3+}$ into perovskite. The first is the coupled substitution $2 \mathrm{Al}^{3+} \rightarrow \mathrm{Al}_{M g}+\mathrm{Al}_{S i}$ where $\mathrm{Al}$ enters both cation sites. Through the second mechanism, $\mathrm{Al}$ replaces $\mathrm{Si}$ in the octahedral site only, and oxygen vacancies are thus required for charge balance.

In order to test whether oxygen vacancies exist in aluminous perovskite, Brodholt [2000] recently calculated the compressibility of end-member defect-bearing perovskites using $a b$ initio methods. For a perovskite with one $\mathrm{Mg}$ and one $\mathrm{Si}$ in the unit cell substituted with $\mathrm{Al},\left(\mathrm{Mg}_{3} \mathrm{Al}\right)\left(\mathrm{Si}_{3} \mathrm{Al}\right) \mathrm{O}_{12}$, the structure does not require the creation of vacancies for charge balance, and the calculated bulk modulus is only $6 \%$ lower than that of Al-free perovskite. At difference, the oxygen- deficient perovskite brownmillerite $\mathrm{Mg}_{2} \mathrm{Al}_{2} \mathrm{O}_{5}$, which has all $\mathrm{Al}^{3+}$ in the octahedral site instead of $\mathrm{Si}^{4+}$, is much more compressible with a calculated $K_{0}$ of $155 \mathrm{GPa}$. The large dependence of the bulk modulus of perovskite on the aluminium content described in the above paragraph

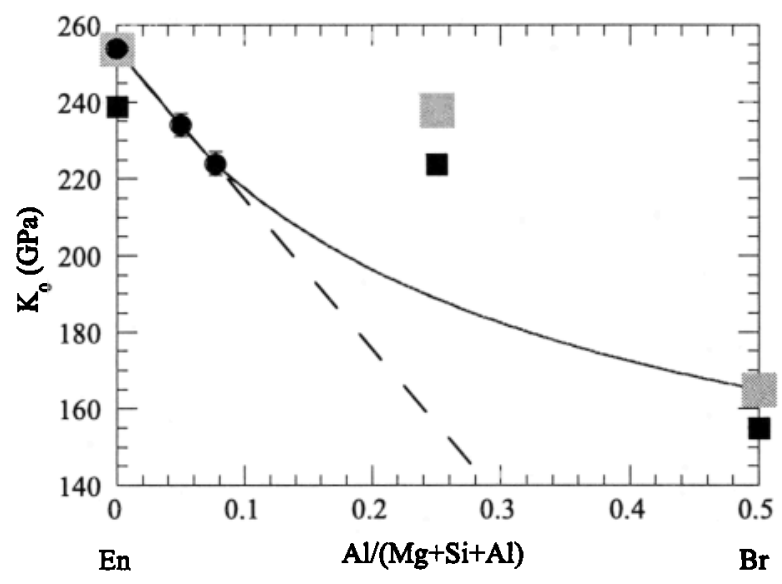

Figure 5. Evolution of the compressibility of perovskite as a function of its Al-content. All bulk moduli reported are valid within the $0-10 \mathrm{GPa}$ range $\left(\mathrm{K}_{0}^{\prime}=4\right)$. Filled circles include the bulk moduli experimentally determined by Ross and Hazen [1990], Zhang and Weidner [1999], and the present results. Empty squares depict the bulk moduli calculated by Brodholt [2000], for the vacancy-free $\mathrm{MgSiO}_{3}(\mathrm{En}),\left(\mathrm{Mg}_{3} \mathrm{Al}\right)\left(\mathrm{Si}_{3} \mathrm{Al}\right) \mathrm{O}_{12}$ perovskites, and for the oxygen deficient $\mathrm{Mg}_{2} \mathrm{Al}_{2} \mathrm{O}_{5}$ brownmillerite $(\mathrm{Br})$; solid grey squares represent the corresponding expected experimental values, typically $7-8 \%$ higher [Brodholt, 2000]. A linear fit to the experimental values (dashed line) indicates a very steep dependence of $K_{0}$ on the Al-content in perovskite. The solid line is an interpolation between available experimental values, and the only plausible value estimated at higher Al-content for brownmillerite. 
provides the experimental confirmation of the hypothesis submitted by Brodholt [2000] that $\mathrm{Al}_{2} \mathrm{O}_{3}$ was likely to be introduced into $\mathrm{MgSiO}_{3}$ perovskite in the form of the oxygen vacancy brownmillerite structure, rather than in place of $\mathrm{Mg}$ and $\mathrm{Si}$ through a coupled substitution (Fig. 5).

\section{Geophysical implications}

From the present results, we may conclude that for alumina content characteristic of the lower mantle ( $\sim 5 \mathrm{~mol} \%)$, all aluminium could be incorporated in perovskite by an oxygen vacancy mechanism, at least in the shallower part of the lower mantle [Brodholt, 2000]. The presence of $\mathrm{Al}^{3+}$ in the octahedral site and of oxygen vacancies in perovskite has various implications for both the geochemistry and the geophysics of the top of the lower mantle.

Aluminous perovskite might incorporate significant amount of hydroxyl, if as in ceramic proton-conducting perovskites, hydration of vacant oxygen sites is energetically favorable [Navrotsky, 1999]. This would strongly contrast with pure $\mathrm{MgSiO}_{3}$ perovskite which does not dissolve any detectable amount of water [Bolfan-Casanova et al., 2000]. Hence, aluminous perovskite might absorb water from the subducting slabs which penetrate the $660 \mathrm{~km}$ discontinuity [Van der Hilst, 1995], and the upper part of the lower mantle might be hydrated.

Finally, the chemical compositions of the lower mantle deduced from mineral physics considerations have been shown to be extremely sensitive to thermoelastic properties of the perovskite phase. The lower mantle has been shown to be either consistent with a pyrolitic composition [Wang et al., 1994; Fiquet et al., 1998], or with a distinct composition enriched in $\mathrm{Si}$ [Stixrude et al., 1992]. Some consensus exists that, due to the high incompressibility of silicate perovskite compared to that of the lower mantle, only quite hot lower mantle models would be consistent with perovskite-enriched compositions [Gillet et al., 2000]. Smaller bulk modulus values induced by the presence of aluminium in silicate perovskite could thus revive the pertinency of silica-rich lower mantle models and of silicate earth stratification as far as chemical composition in major elements is concerned [Javoy, 1995]. In any case, the present results indicate that it is now absolutely necessary to take into account the elastic effects of $\mathrm{Al}$ in perovskite for assessing the $\mathrm{Si} / \mathrm{Mg}$ ratio of the lower mantle, and thus the large-scale stratification of the Earth's mantle.

Acknowledgments. Helium was loaded in the diamond anvil cell using the high-pressure gas loading device developed at the Laboratoire de Physique des Milieux Condensés (UMR 7602) in Paris. The authors warmly thank J.-C. Chervin and B. Cousinet for their help.

\section{References}

Bolfan-Casanova, N., H. Keppler, and D.C. Rubie, Water partitioning between nominally anhydrous minerals in the $\mathrm{MgO}$ $\mathrm{SiO}_{2}-\mathrm{H}_{2} \mathrm{O}$ system up to $24 \mathrm{GPa}$, Earth Planet. Sci. Lett., 182, 209-221, 2000.

Brodholt, J.P., Pressure-induced changes in the compression mechanism of aluminous perovskite in the Earth's mantle, $\mathrm{Na}$ ture, 407, 620-622, 2000.

Dziewonsky, A.M., and D.L. Anderson, Preliminary Reference Earth Model, Phys. Earth Planet. Inter. 25,-297-356, 1981.

Fiquet, G., A. Dewaele, D. Andrault, M. Kunz, and T. Le Bihan, Thermoelastic properties and crystal structure of $\mathrm{MgSiO}_{3}$ perovskite at lower mantle pressure and temperature conditions, Geophys. Res. Let., 27, 21-24, 2000.
Fiquet, G., D. Andrault, A. Dewaele, T. Charpin, M. Kunz, and D. Hausermann, P-V-T equation of state of $\mathrm{MgSiO}_{3}$ perovskite, Phys. Earth Planet. Inter., 105, 21-32, 1998.

Gillet, P., I. Daniel, F. Guyot, J. Matas, and J.C. Chervin, A thermodynamic model for $\mathrm{MgSiO}_{3}$ perovskite derived from the pressure, temperature and volume dependence of the Raman mode frequencies, Phys. Earth Planet. Inter., 117, 43-54, 2000.

Hammersley, A.P., FIT2D: an introduction and overview, Tech. Rep. ESRF-97-HA-02T, ESRF, Grenoble, 1997.

Irifune, T., T. Koizumi, and J.I. Ando, An experimental study of the garnet-perovskite transformation in the system $\mathrm{MgSiO}_{3}$ $\mathrm{Mg}_{3} \mathrm{Al}_{2} \mathrm{Si}_{3} \mathrm{O}_{12}$, Phys. Earth Planet. Inter., 96, 147-157, 1996.

Irifune, T., Absence of an aluminous phase in the upper part of the Earth's lower mantle, Nature, 370, 131-133, 1994.

Javoy, M., The integral enstatite chondrite model of the Earth, Geophys. Res. Let., 22, 2219-2222, 1995.

Kesson, S.E., J.D. Fitz Gerald, J.M.G. Shelley, and R.L. Withers, Phase relations, structure and crystal chemistry of some aluminous silicate perovskite, Earth Planet. Sci. Lett., , 134, 187-201, 1995.

Kubo, A., and M. Akaogi, Post-garnet transformation in the system $\mathrm{Mg}_{4} \mathrm{Si}_{4} \mathrm{O}_{12}-\mathrm{Mg}_{3} \mathrm{Al}_{2} \mathrm{Si}_{3} \mathrm{O}_{12}$ up to $28 \mathrm{GPa}$ phase relations of garnet, ilmenite and perovskite, Phys. Earth Planet. Inter., 121, 85-102, 2000.

Larson, A.C., and R.B. Von Dreele, General System Analysis System, Tech. Rep. LAUR-TR-77-02721, AD-A059242, Los Alamos Nat. Lab., 1988.

McCammon, C.A., Perovskite as a possible sink for ferric iron in the lower mantle, Nature, 387, 694-696, 1997.

Navrotsky, A., A lesson from ceramics, Science, 284, 1788-1789, 1999.

O'Neill, B., and R. Jeanloz, $\mathrm{MgSiO}_{3}-\mathrm{FeSiO}_{3}-\mathrm{Al}_{2} \mathrm{O}_{3}$ in the Earth's lower mantle: Perovskite and garnet at $1200 \mathrm{~km}$ depth, $J$. Geophys. Res., 99, 19901-19915, 1994.

Ross, N.L., and R.M. Hazen, High-pressure crystal chemistry of $\mathrm{MgSiO}_{3}$ perovskite, Phys. Chem. Miner., 17, 4228-4237, 1990.

Shim, S.-H., T.S. Duffy, and G. Shen, The stability and P-V-T equation of state of $\mathrm{CaSiO}_{3}$ perovskite in the Earth's lower mantle, J. Geophys. Res., 105, 25955-25968, 2000.

Stixrude, L., R.J. Hemley, Y. Fei, and H.K. Mao, Thermoelasticity of silicate perovskite and magnesiowstite and stratification of the Earth's mantle, Science, 257, 1099-1101, 1992.

Van der Hilst, R.D., Complex morphology of subducted lithosphere in the mantle beneath the Tonga trench, Nature, 374, 154-157, 1995.

Wang, Y.B., D.J. Weidner, and F. Guyot, Thermal equation of state of $\mathrm{CaSiO}_{3}$ perovskite, J. Geophys. Res., 101, 661-672, 1996.

Wang, Y.B., D.J. Weidner, R.C. Liebermann, and Y.S. Zhao, P$\mathrm{V}-\mathrm{T}$ Equation of State of $(\mathrm{Mg}, \mathrm{Fe}) \mathrm{SiO}_{3}$ Perovskite - Constraints on Composition of the Lower Mantle, Phys. Earth Planet. Inter., $83,13-40,1994$.

Wood, B.J., and D.C. Rubie, The effect of alumina on phase transformations at the 660 -kilometer discontinuity from $\mathrm{Fe}-\mathrm{Mg}$ partitioning experiments, Science, 273, 1522-1524, 1996.

$\mathrm{Xu}, \mathrm{Y}$., C. McCammon, and B.T. Poe, The effect of alumina on the elctrical conductivity of silicate perovskite, Science, 282, 922-924, 1998.

Zhang, J., and D. Weidner, Thermal equation of state of aluminium-enriched silicate perovskite, Science, 284, 782-784, 1999 .

H. Cardon and I. Daniel, Laboratoire de Dynamique de la Lithosphère, Université Claude Bernard Lyon 1, Bat 402, 43 bd du 11 Novembre 1918, F-69622 Villeurbanne cedex, France. (email:Isabelle.Daniel@univ-lyonI.fr)

G. Fiquet and F. Guyot, Laboratoire de MinéralogieCristallographie, Université Paris-Jussieu, Tour 16 Case 115, 4 place Jussieu, F-75252 Paris cedex 05, France.

M. Mezouar, ESRF, 6 rue Jules Horowitz, BP-220-F-38043 Grenoble cedex 9, France.

(Received February 13, 2001; revised April 06, 2001; accepted May 05, 2001.) 